\title{
INVESTIGATION OF SILICON CARBIDE POLYTYPES BY RAMAN SPECTROSCOPY
}

\author{
G. Chikvaidze ${ }^{1}$, N. Mironova-Ulmane ${ }^{1}$, A. Plaude ${ }^{1}$, O. Sergeev ${ }^{2}$, \\ ${ }^{1}$ Institute of Solid State Physics, University of Latvia, \\ 8 Ķengaraga Str., LV-1063, Rīga, LATVIA \\ ${ }^{2}$ V.E.Lashkaryov Institute of Semiconductor Physics, \\ National Academy of Science of the Ukraine, \\ 41 Nauki Ave., 03028, Kyiv, the UKRAINE \\ e-mail: georgc@cfi.lu.lv
}

\begin{abstract}
Polytypes of colourless and coloured single crystals of silicon carbide ( $\mathrm{SiC})$ grown on $\mathrm{SiC}$ substrates by chemical vapour deposition are studied using Raman spectroscopy supplemented by scanning electron microscopy (SEM) and X-ray diffraction (XRD) analyses. The SEM analysis of the defect stacking faults, inclusions of defects and their distribution has shown that they correlate with the peak positions of the obtained Raman spectra and with the XRD data on the crystal structure.
\end{abstract}

Keywords: Silicon carbide (SiC), polytypes, Raman spectroscopy, $X$-ray diffraction $(X R D)$.

\section{INTRODUCTION}

Silicon carbide ( $\mathrm{SiC}$ ) is a highly attractive material for fabrication of microelectronic and optoelectronic devices due to its wide band gap, high thermal conductivity, excellent thermal and chemical stability as well as its resistance to radiation damage and electrical breakdown [1]. As known, silicon carbide crystallizes in many polytypes of so-called polymorphs, their total number exceeding 200 [2]. The list of the most common polytypes includes $3 \mathrm{C}, 2 \mathrm{H}, 4 \mathrm{H}$, $6 \mathrm{H}, 8 \mathrm{H}, 9 \mathrm{R}, 10 \mathrm{H}, 14 \mathrm{H}, 15 \mathrm{R}, 19 \mathrm{R}, 2 \mathrm{OH}, 21 \mathrm{H}$, and $24 \mathrm{R}$, where $(\mathrm{C}),(\mathrm{H})$ and $(\mathrm{R})$ are the basic crystallographic categories: cubic, hexagonal and rhombohedral. In the cubic category, zinc-blend structures are labelled $3 \mathrm{C}-\mathrm{SiC}$ or $\beta$-SiC. The hexagonal category is represented by $n \mathrm{H}-\mathrm{SiC}$ and the rhombohedral - by $n \mathrm{R}-\mathrm{SiC}$ polytypes, which are generally referred to as $\alpha-\mathrm{SiC}, n \mathrm{Si}-\mathrm{C}$ bilayers consisting of $\mathrm{C}$ - and $\mathrm{Si}$ layers stacked in a unit cell [2].

The most common forms are $4 \mathrm{H}, 6 \mathrm{H}$ (known as hexagonal $\alpha$-SiC types), and the cubic 3C-SiC type ( $\beta$-SiC) [2]. Among diversified polytypes, the 3C-SiC variety possesses unique properties, including a high electron mobility up to 1000 $\mathrm{cm}^{2} / \mathrm{V} \cdot \mathrm{s}$ and a consequent high saturation drift velocity. Therefore, reproducible growth of $\mathrm{SiC}$ single crystals on silicon or silicon carbide substrate is of high 
importance for the semiconductor industry. The limitations of $\mathrm{SiC}$ technologies stem from structural defects (point defects, line (or 2D) defects, stacking faults), which adversely affect the operation of semiconductor devices. Single crystals of a high-purity cubic polytype are usually colourless or yellow, while of $6 \mathrm{H}$ polytypes - grey or green. The colour of a crystal depends on the type of impurity and its concentration in the crystal. By varying the nitrogen content in a $6 \mathrm{H}-\mathrm{SiC}$ polytype crystal it is possible to change its colour from a translucent light green to the opaque dark green.

In the present work, the Raman spectroscopy - a fast and contact-free method with easy sample preparation - supplemented by X-ray diffraction (XRD) and scanning electron microscopy (SEM) techniques was applied for characterization of $\mathrm{SiC}$ polytypes [3,4] and impurities in $\mathrm{SiC}$ [5]. Under study are colourless and coloured silicon carbide single crystals grown on $\mathrm{SiC}$ substrates by chemical vapour deposition using the Raman spectroscopy in combination with the SEM and XRD analyses.

\section{EXPERIMENTAL}

All investigated $\mathrm{SiC}$ samples were grown by direct synthesis from silicon and carbon vapours in deep vacuum in a quasi-closed system of high-purity graphite. The samples were deposited onto $\mathrm{SiC}$ substrates. The grown $\mathrm{SiC}$ single crystals differed in colour and transparency depending on the conditions during the growth process. Our experiments were carried out with colourless and coloured (grey, yellow, blue and green) SiC single crystals. Investigation of their physical properties has shown that the crystal colour is determined primarily by the polytype, and only then by the influence of impurities entering the crystal during growth.

The morphology of the as-synthesized $\mathrm{SiC}$, its defective structure and the density of defects were studied by means of optical microscopy and using a scanning electron microscope (SEM, TESCAN Mira LMU FEG). The chemical composition of samples was analyzed with the energy-dispersive X-ray spectroscopy (EDX, Oxford System embedded in the SEM). The SiC crystal structure was analyzed using $\mathrm{Cu} \mathrm{K \alpha}$ radiation (a PANalytical X'Pert PRO X-ray diffraction system).

The micro-Raman scattering measurements were carried out at room temperature (RT) in the backscattering geometry using an Advantage Raman NIR spectrometer (resolution $3 \mathrm{~cm}^{-1}, 785 \mathrm{~nm}$ laser) and a Spex Ramalog Raman spectrometer (resolution $1 \mathrm{~cm}^{-1}, 532 \mathrm{~nm}$ and $633 \mathrm{~nm}$ lasers).

\section{RESULTS AND DISCUSION}

\section{Sample growing}

For growing the $\mathrm{SiC}$ single crystals an original technology and a specially designed device were applied. The technology [6] is based on the method of direct 
$\mathrm{SiC}$ synthesis from silicon and carbon in different phases: silicon - as liquid or vapour, and carbon (graphite) - as solid (vaporizes at the temperature of $2000^{\circ} \mathrm{C}$ and vacuum of $10^{-5}-10^{-6} \mathrm{mBar}$ ).

The synthesis of $\mathrm{SiC}$ proceeds in the region above the melt due to high concentration of silicon and carbon vapours and high temperature. Once the SiC compound is formed, in the presence of a temperature gradient these vapours move to the cooler zone and deposit on the substrate where a crystal is growing.

To find the optimal conditions of $\mathrm{Si}$ evaporation and $\mathrm{SiC}$ synthesis as well as the optimal temperature gradients, the crystal growth rates and the design of equipment, in the experiments we varied the temperatures of $\mathrm{Si}$ evaporation, $\mathrm{SiC}$ synthesis and crystal growth. Since the most valuable SiC crystals - both coloured and colourless - are those without defects, the greatest challenge for us was to grow $\mathrm{SiC}$ crystals with minimum defects. The defects in $\mathrm{SiC}$ crystals that are optically visible are the following: splices of different polytypes, voids, cracks, inclusions, etc. Most of these defects arise owing to the presence of impurities in the growing crystal.

\section{X-ray diffraction}

The X-ray diffraction picture of the obtained grey single crystals shows a good compliance of the most intense peaks with the hexagonal $6 \mathrm{H}-\mathrm{SiC}$ polytype. This was revealed on the 002 and 004 peaks corresponding to the lattice parameters $\mathrm{a}=3.0763 \mathrm{~A}^{\circ}$ and $\mathrm{c}=15.080 \mathrm{~A}^{\circ}$. The crystal surface is oriented parallel to the (002) plane. Simultaneously, aside from the diffraction maxima typical of the (002) plane (and of the equivalent ones) with the intensities characteristic of a single crystal's diffraction maxima, separate low-intensity peaks are observed, which is indicative of small crystallite inclusions of another orientation.

In the green $\mathrm{SiC}$ single crystal with defects the intense 002 and 004 peaks are observed that correspond to the hexagonal triclinic structure of $2 \mathrm{H}-\mathrm{SiC}$ with lattice parameters $\mathrm{a}=0.3076 \mathrm{~nm}$ and $\mathrm{c}=0.5048 \mathrm{~nm}$ and cubic structure $3 \mathrm{C}-\mathrm{SiC}$ with $\mathrm{a}=0.4359 \mathrm{~nm}$. The crystal surface is oriented parallel to the (111) plane.

XRD patterns of the green SiC single crystal with defects are shown in Fig.1. The peaks in Fig.1 are identified as belonging to the hexagonal polytypes $\mathrm{K}_{\alpha 1}$ and $\mathrm{K}_{\alpha 2} 2 \mathrm{H}-\mathrm{SiC}$ and the cubic polytypes $\mathrm{K}_{\alpha 1}$ and $\mathrm{K}_{\alpha 2} 3 \mathrm{C}$-SiC.

The $3 \mathrm{C}-\mathrm{SiC}$ and $2 \mathrm{H}-\mathrm{SiC}$ polytypes are stable in the temperature range from $1300^{\circ} \mathrm{C}$ to $1600^{\circ} \mathrm{C}$, while the $2 \mathrm{H}-\mathrm{SiC}$ polytype transforms to the $3 \mathrm{C}-\mathrm{SiC}$ polytype at temperatures $1400-1800^{\circ} \mathrm{C}$.

Figure 2 shows the SEM image of the green SiC single crystal with defects.

To determine the chemical composition of the green single crystal with defects, the EDX measurements were taken using SEM - separately for the areas with and without defects. The EDX analysis has shown that all the samples contain only silicon and carbon. The results evidence that the atomic percentage of carbon is higher in the defect-free areas $(\mathrm{C}-54-56 \%$ and $\mathrm{Si}-44-46 \%)$ than in those with defects $(\mathrm{C}-33-35 \%$ and $\mathrm{Si}-65-67 \%)$. 


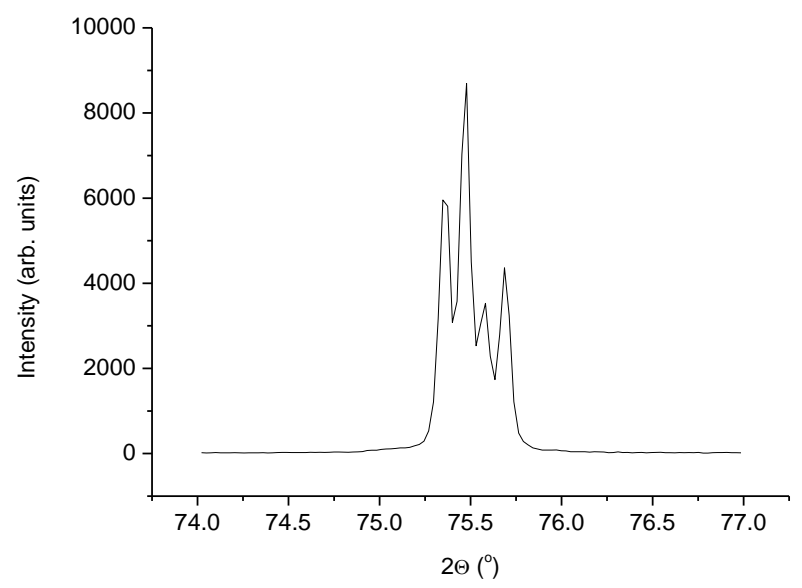

Fig.1. XRD pattern of the green $\mathrm{SiC}$ single crystal with defects.

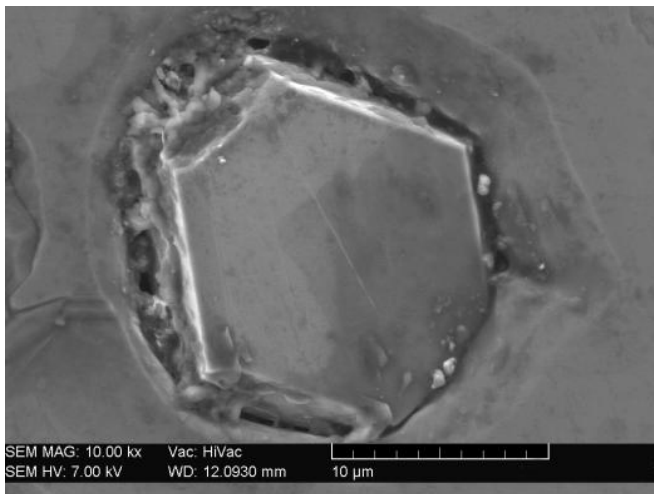

Fig.2. SEM image of the SiC green single crystal with defects.

\section{Raman Spectroscopy}

The results of Raman analysis performed for two samples: the colourless SiC single crystal and the grey SiC single crystal are presented in Fig.3 and Table 1.

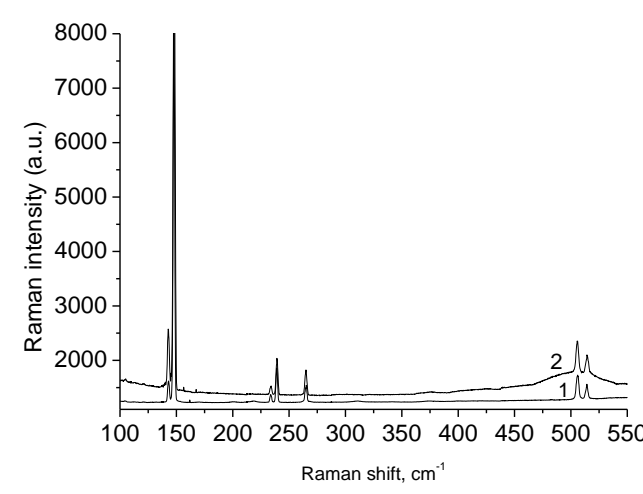

a)

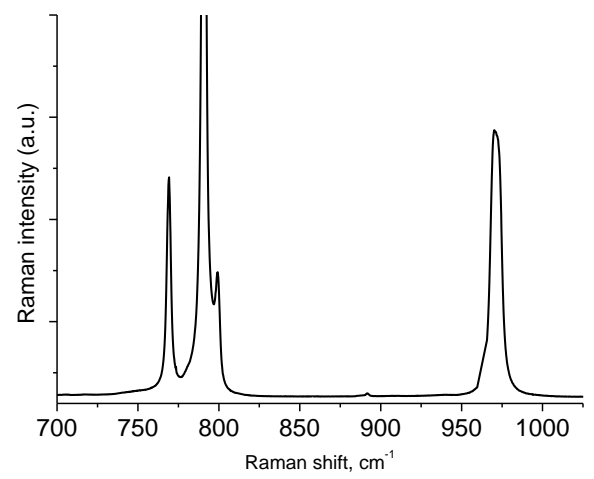

b)

Fig.3. RT micro-Raman spectra of:

a) 1 - colourless $\mathrm{SiC}$ single crystal, 2 - grey $\mathrm{SiC}$ single crystal (Raman shift $100-550 \mathrm{~cm}^{-1}$ ); b) colourless $\mathrm{SiC}$ single crystal (Raman shift $700-1000 \mathrm{~cm}^{-1}$ ). 
Raman spectra of colourless and grey single crystals in Fig. 3 and their frequencies (Raman shifts) in Table 1 are indicative of polytype $6 \mathrm{H}-\mathrm{SiC}$, which is in agreement with the data reported in [7]. All 6H-SiC samples possess the hexagonal wurtzite structure, which is confirmed by the X-ray diffraction measurements.

Raman shifts of the peaks shown in Fig.3a,b with reference to [7]

\begin{tabular}{|c|c|c|l|}
\hline $\begin{array}{c}\text { Colourless single crystal } \\
\text { Raman shift, } \mathbf{c m}^{-\mathbf{1}}\end{array}$ & $\begin{array}{c}\text { Grey single crystal } \\
\text { Raman shift, } \mathbf{c m}^{-\mathbf{1}}\end{array}$ & $\begin{array}{c}\text { 6H-SiC peak [7] } \\
\text { Raman shift, } \mathbf{c m}^{-\mathbf{1}}\end{array}$ & \multicolumn{1}{|c|}{ Phonon Mode [7] } \\
\hline $143, \quad 148$ & $143, \quad 148$ & $146.0, \quad 150.5$ & E2 planar acoustic \\
\hline $234, \quad 238$ & $234, \quad 239$ & $235.0,240.0$ & E1 planar acoustic \\
\hline 265 & 265 & 266.0 & E2 planar acoustic \\
\hline 506,514 & 504,515 & $505.0,513.5$ & A1 axial acoustic \\
\hline 769,791 & 769,791 & $767.5,788.0$ & E2 planar optic \\
\hline 799 & 798 & 796.0 & E1(TO) \\
\hline 892 & 892 & 888.5 & A1 axial optic \\
\hline 970 & 970 & 966.5 & A1(LO) \\
\hline
\end{tabular}

Figure 4 shows micro-Raman spectra of the green $\mathrm{SiC}$ single crystal for the areas with and without defects.

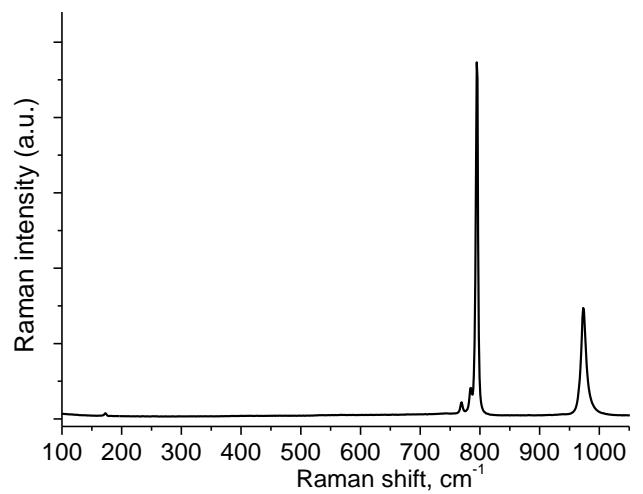

a)

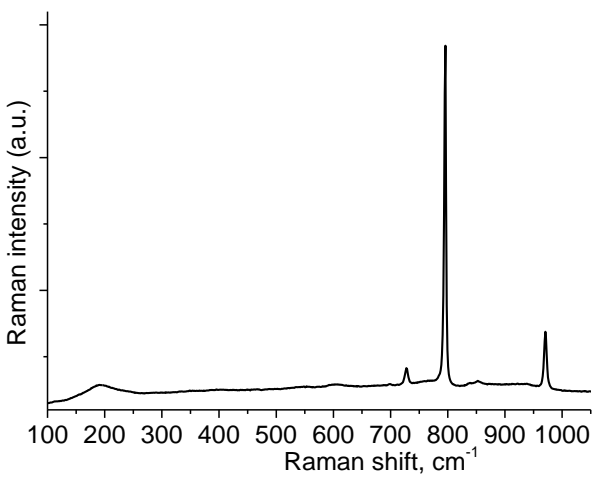

b)

Fig.4. Micro-Raman spectra of the green SiC single crystal:

(a) defect-free area;

(b) area with defects.

The results of measuring the Raman spectrum of green SiC single crystal (Fig.4a) evidence that the defect-free area of the sample presents a cubic polytype $3 \mathrm{C}$-SiC of the $795 \mathrm{~cm}^{-1}$ transverse optical (TO) mode and $973 \mathrm{~cm}^{-1}$ longitudinal 
optical (LO) mode [8], and a 15R-SiC polytype with small crystallite inclusions (770 $\mathrm{cm}^{-1}$ (TO) and $172 \mathrm{~cm}^{-1}$ transverse acoustic (TA) mode). Figure $4 b$ shows a typical Raman spectrum for the area of green $\mathrm{SiC}$ single crystal where the growth defects are observed. The Raman peaks of about 796 and $971 \mathrm{~cm}^{-1}$ correspond to the peaks of a rarer polytype $2 \mathrm{H}-\mathrm{SiC}$. The broad peak at $200 \mathrm{~cm}^{-1}$ can be attributed to the TA mode, the peaks at 728 and $786 \mathrm{~cm}^{-1}-$ to the TO mode, and the peak at $971 \mathrm{~cm}^{-1}$ - to the LO mode [9].

\section{CONCLUSIONS}

Raman spectra of different silicon carbide polytypes grown using our original method are helpful in detection of the defects in single crystals and of the presence of different phases (polytypes) which may arise in the volume of the main single crystal due to minor changes in the temperature or in other parameters during the process of crystal growth.

\section{ACKNOWLEDGMENTS}

This work is supported by ERAF Project No. 2010/0245/2DP/2.1.1.0/10/ APIA/VIAA/114.

\section{REFERENCES}

1. Pensl, G., \& Choyke, W.J. (1993). Electrical and optical characterization of SiC. Physica B, 185, 264-283.

2. Cheung, R. (2006). Silicon Carbide Microelectromechanical Systems for Harsh Environments. Imperial College Press, Ch. 3, ISBN 1860946240.

3. Shenghuang Lin, Zhiming Chen, Lianbi Li, Yintu Ba, Sujuan Liu, \& Mingchao Yang (2012). Investigation of micropipes in $6 \mathrm{H}-\mathrm{SiC}$ by Raman scattering. Physica, B40, 670-673.

4. Nakashima, S., \& Harima, H. (1997). Raman investigation of SiC polytypes. Phys. Status Solidi (a), 162, 39.

5. Shenghuang Lina, Zhiming Chena, Lianbi Lib, \& Chen Yanga (2012). Effect of impurities on the Raman scattering of $6 \mathrm{H}-\mathrm{SiC}$ crystals. Materials Research, 15 (6), 833-836.

6. Sergeev O.T., \& Mosol I.V. Patent 52151 of 20.06.2010. A method for growing single crystals of silicon carbide-almanita.

7. Burton, J.C., Sun, L., Pophristic, M., Lukacs, S.J., Long, F.H., Feng, Z.C., \& Ferguson, I.T. (1998). J. Appl. Phys., 84, 6268.

8. Lee, C.J., Pezzotti, G., Okui, Y., \& Nishino, S. (2004). Raman microprobe mapping of residual microstresses in 3C-SiC film epitaxial lateral grown on patterned $\mathrm{Si}$ (111). Applied Surface Science, 228, 10-16.

9. Huan Zhang, Weiqiang Ding, Kai He, \& Ming Li. (2010). Synthesis and characterization of crystalline silicon carbide nanoribbons. Nanoscale Res. Lett., (5), 1264-1271. 


\section{SILĪCIJA KARBĪDA POLITIPU PĒTĪJUMI AR RAMANA SPEKTROSKOPIJU}

G. Čikvaidze, N. Mironova-Ulmane, A. Plaude, O. Sergeev

\section{Kopsavilkums}

Dažādu fāzu silīcija karbīda (SiC) monokristāli, kas audzēti uz SiC pamatnēm ar ķ̄imiskās nogulsnēšanas metodi no gāzveida fāzes, tika pētīti, izmantojot Ramana spektroskopiju, skenējošo elektronu mikroskopiju (SEM) un rentgenstaru difrakciju (XRD). Ar SEM palīdzību tika identificēti kristalogrāfiskās struktūras apgabali un ieslēgumi, ir pierādīts, ka tie korelē ar Ramana spektru pīķu pozīijāâm, un XRD datiem par kristālisko struktūru.

20.12.2013. 